\title{
The Present and Future of the Sino-South Korean Fisheries Dispute: A Chinese Lawyer's Perspective
}

Zewei Yang *

The Sino-South Korea fisheries dispute is becoming increasingly intensified in recent years with occasional violent conflicts. The factors leading to this present situation include unsettled maritime delimitation, diminishing fishery resources, difficult relocation of Chinese fishermen, and the Korean coastguard's rigidity, indifference, and even illegality in law enforcement. In order to solve the Sino-South Korean fisheries dispute, China should make efforts to improve its supporting measures applicable to the fishery industry, promote bilateral cooperation with South Korea, and establish a joint maritime enforcement mechanism.

\section{Keywords}

Sino-South Korea Fishery Agreement, Fisheries Dispute, Yellow Sea, South Korean Coastguard, Fisheries Industry, UNCLOS

* Luojia Distinguished Professor at Wuhan University School of Law, P.R. China. A.B.(Hunan Normal Univ.), M.A./Ph.D.(Wuhan Univ.). The author may be contacted at: yangzewei@hotmail.com / Address: This article is a part of the research project, "Territorial Disputes Settlement Mechanism in International Law - China's Choice" (Project No. NCET-08-0426), sponsored by the Program for New Century Excellent Talents, the Ministry of Education, China. The opinions expressed herein are those of the author alone. 


\section{Introduction}

The Yellow Sea is a turbulent maritime area in East Asia as shown by the warship Cheonan incident ${ }^{1}$ and the Bombardment of Yeonpyeong Island, ${ }^{2}$ which aroused international concerns. In particular, two occasions involving ships called Lu Wen $\mathrm{Yu}$ (鲁文渔) ${ }^{3}$ and Zhe Tai Yu Yun (浙台渔运), 4 triggered civilian antagonism between China and South Korea. Although the Sino-South Korea Fishery Agreement was signed in 2000 and took effect in 2001, encouraging cooperative fisheries management in the Yellow Sea, this agreement has not effectively stopped fisheries dispute in this area.

This article aims to analyze the status of the Sino-South Korean fisheries dispute and proposes tentative suggestions that could lead to a peaceful settlement. This article is composed of five parts including Introduction and Conclusion. Part two will analyze the characteristics of Sino-South Korean fisheries dispute at present. Part three will probe into the causes of the dispute. Finally, Part four will make some tentative suggestions for a pacific settlement of the Sino-South Korean fisheries dispute.

1 On the evening of March 26, 2010, The Cheonan, a South Korean warship, was sailing off Baengnyeong Island close to the disputed inter-Korean maritime border. An explosion split it in two and it sank. Fifty-eight sailors managed to escape, but 46 were killed. See Chronology of Chonan Sinking, Korea Times, Apr. 29, 2010, available at http://www.koreatimes.co.kr/www/news/nation/2010/04/116_65091.html (last visited on Oct. 18, 2012).

2 The Bombardment of Yeonpyeong Island was an artillery engagement between the North Korean military and South Korean forces stationed on Yeonpyeong Island on November 23, 2010. Following a South Korean artillery exercise in waters adjacent to Yeonpyeong Island, North Korean forces warned and fired artillery shells and rockets at Yeonpyeong Island at 14:00. South Korea retaliated by shelling North Korean gun positions. The North Koreans subsequently stated that they had responded to South Korean shells being fired into North Korean territorial waters. The shelling caused widespread damage on both sides and an escalation of the tension on the Korean Peninsula. See Sang-ho Song, N.K. artillery strikes S. Korean island, Korea Herald, Nov. 23, 2010, available at http://khnews.kheraldm.com/view.php?ud=20101123001048\&md=20101123224940_AK (last visited on Oct. 18, 2012).

3 On December 12, 2011, a Chinese fishing boat, Lu Wen Yu, went for fishing in the disputed waters, and Captain Cheng Dawei, in what he alleged was a conditioned response, wielded a knife and killed an officer after abrupt flash bombs from the coast guard. Cheng and eight other fishermen were detained subsequently. Invoking the exclusive economic zone ("EEZ") Law of the Republic of South Korea ("ROK"), the local court of Incheon on April 19, 2012 sentenced captain Cheng to imprisonment for 30 years and a fine of 20 million Korean Won (USD 17,560) for stabbing an ROK coastguard officer to death. In response to this verdict, Ministry of the Foreign Affairs ("FM") spokesman Liu Weimin said at the regular FM press conference, "China has taken note of the verdict. China and the ROK have not demarcated the limits of their EEZs in the Yellow Sea, thus China does not accept the ROK's unilateral application of its law on EEZs to make such a verdict over Chinese fishermen." See Regular Press Conference on April 19, Ministry of the Foreign Affairs, available at http://www.fmprc.gov.cn/chn/gxh/tyb/fyrbt/ jzhsl/t924474.htm (last visited on Oct. 27, 2012).

4 A Chinese fishing boat, Zhe Tai Yu Yun, went to purchase fish in the disputed waters on January 17, 2012. South Korean coastguards forcefully boarded the boat and brutally attacked its crew members. Later on, Captain Wang Xiaofu and others were taken to Jeju Island. On April 16, the court in Jeju Island granted summary judgment, holding that Wang impeded the South Korean officers' law enforcement action and he was fined 80 million ROK won (USD 72,000). 


\section{The Characteristics of Sino-South Korean Fisheries Dispute}

The fisheries dispute between China and South Korea may date back to the mid-1950s. In 1956, the South Korean navy detained three Chinese fishermen for cross-border fishing and China detained three South Korean sailors in response. The incident ended up with an exchange of detainees. 5 Fisheries disputes also occurred occasionally in the Yellow Sea during early 1990s. As China and South Korea established a diplomatic relationship in 1992, both the countries initiated discussions intended to maintain relations through tacit mutual understandings. In the course of diplomatic negotiations and building an ambassadorial relationship, however, the two countries set aside the fisheries issue because of the huge gap between them; this left a "gray area" of fishing and law enforcement for both the parties. 6 The following are the characteristics of the fisheries disputes between China and South Korea which is getting more intensive recently.

\section{A. Numerous Disputes Are Related to Fishing Boats}

Statistics show that South Korea detained 2,037 Chinese fishing boats under accusations of 'illegal operation' from 2004 to 2007 and arrested 20,896 Chinese fishermen.7 Those fishermen paid bail in total amounting to 21,355 billion won (approximately 119 million RMB). ${ }^{8}$ In 2010, South Korea detained 104 fishing boats with the same charge. Since 2011, especially, the South Korean Coast Guard ("KCG") has been detaining Chinese fishing boats more frequently. ${ }^{9}$ On March 3, 2011, The KCGs detained two Chinese fishing boats on suspicion of 'illegal operation' ; again on September 27, 2011, South Korea's "West Sea Fisheries Supervision Office" captured one fishing boat on suspicion of 'illegal operation' in its so-called exclusive economic zone ("EEZ"). Two days later, the KCG detained another fishing boat in the adjacent waters of Heuksando Island; then, on October 22, the KCG captured three Chinese fishing boats and 31 fishermen, claiming to intend to prosecute five of them on charge of impeding law enforcement,

\footnotetext{
Zhihua Lei, Pains in Sino-South Korea Fisheries Dispute, For THE PuBlic Good [Nanfengchuang] 34 (2012). Zhihua Lei, Politics in Fisheries Dispute, For THE PuBLIC Good [Nanfengchuang] 31 (2012).

Tao Xiong \& Bin Che, A Study on the Causes and Solution of Sino-South Korean Fisheries Dispute, 7 Shandong FISHERIES 52 (2009).

9 See South Korean Coast guard Stabbed to Death by Chinese Fisherman (available only in Chinese), IFENG NEws, Dec. 12, 2011, available at http://www.ibtimes.com/south-korean-coast-guard-stabbed-chinese-fisherman-official-382030 (last visited on Oct. 28, 2012).
}

$8 \quad I d$. 
but resolving the case through a fine three days later. Between November 26 and 27, The KCG detained 26 Chinese fishing boats under charge of 'illegal operation' ; finally, on December 22, The KCG detained two more Chinese fishing boats, Lu Wen Yu and Liao $\mathrm{Hu} \mathrm{Yu}$ (辽葫渔) with 10 fishermen. The fisheries dispute between China and South Korea shows no sign of cessation. An editorial of The Seoul Shinmun Daily exclaimed: "The Yellow Sea has become a battlefield."10

The numerous fisheries disputes are mainly due to South Korea's broad definition of so-called 'illegal operation.' To be specific, South Korea punishes Chinese fishing boats based on the following grounds: (1) Entry without license; (2) cross-border fishing in Korea's special non-fishing zone; (3) entry without notification; (4) early entry after notification; (5) fishing without a capacity plan, or fishing with a capacity plan lacking stamping of the applicant's seal; (6) non-conformity of the mesh size of the cod-end of the trawl; and (7) keeping no or irregular fishing logs. 11 Despite the wide scope and harsh punishment, however, it is fair to say that Chinese fishermen can avoid illegal operation' charges by only taking technical measures.

\section{B. Violent Conflicts Abound}

According to the relevant Sino-South Korean agreements, a Chinese fishing boat, once detained because of illegal operation, has to pay a fine in accordance with its size. For a boat below 50 tons, the fine shall be 30 million South Korean won ("KRW"); for a boat over 50 tons, it shall be 50 million KRW. The fisherman shall be arrested if he cannot pay the fine. ${ }^{12}$ Since the fine of 30-50 million KRW means bankruptcy to Chinese fishermen and their families, it is understandable that they would resist with stones, axes, steel pipes, sickles, and sticks in order not to be caught by the KCG. Their resistances sometimes are very strong. E.g., on September 25, 2008, a coastguard officer was found drowned due to an injury by a blunt object after a crash occurred while he was inspecting a Chinese fishing boat. 13 There are other incidents as follows: on December 14, 2008, The KCG officers were attacked by Chinese fishermen with shovels and sticks; on November 19, 2011, five KCG officers were injured in the course of detaining three Chinese fishing boats; on December 12, 2011, one KCG officer was stabbed to death

\footnotetext{
10 See Resisting Chinese Vessels Should Be Forcibly Subdued, The Seoul Shinmun DaIly, Nov. 18, 2011, at 31. See also Fei Yu, Expert Claims That South Korean Verdict of Chinese Fishing Boat Captain is an Erroneous Application of Law, 3 HUBEI LEGAL SCI. 51 (2012).

11 Xiong \& Che, supra note 7.

12 See Regulations on Chinese Fishing Boat Part of the Sino-South Korean Agreements, available at http://news.163.com/11/1227/12/7M9HUU2I00014MN2.html (last visited on Oct. 28, 2012).

13 Supra note 9.
} 
while arresting a Chinese fisherman.14

\section{The KCG's Armed Enforcement Has Escalated the Fisheries Dispute}

Since the death of the coastguard officer on September 2008, the KCG, owing to the intensified public outrage, has begun to undertake stronger measures, such as building special mobile forces and deploying more warships. Furthermore, the KCG allows its officers to use firearms against Chinese fishermen. 15 As a result, the fisheries dispute has further escalated. On December 18, 2010, a 3000-ton patrol ship of the KCG capsized a 63-ton Chinese fishing boat, resulting in two Chinese fishermen dead; on March 3, 2011, the KCG detained two Chinese boats, and one Chinese fisherman was shot. This was the first time that the KCG has fired at Chinese fishermen.16 During the "Zhe Tai Yu Yun" incident in 2012, according to the fishermen, one of the four KCG officers hit their heads and ribs with batons, causing 13 fishermen to be injured severely and three fishermen to fall into coma.17 However, the KCG has denied the illegality, claiming that this incident was caused when Chinese fishermen attempted to grab the coastguards' guns during their normal enforcement of law, and pointing out that coastguards were injured, as well.18

\section{Causes of the Sino-South Korean Fisheries Dispute}

The Sino-South Korean fisheries dispute is a complicated issue for both the countries to address, in general, because of the following five reasons:

\section{A. The Unsettled Maritime Demarcation in the Yellow Sea}

In principle, a fisheries agreement between two States will not be signed before the demarcation of their EEZs is settled because such an agreement usually allows the other

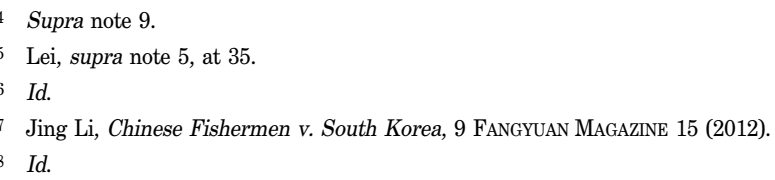


country to carry out fishing operations in specific waters of one's EEZ. Nevertheless, the Sino-South Korea Fishery Agreement was signed as a provisional accord without the definite demarcation of EEZs in order to meet the prompt requirements for the bilateral fisheries order. ${ }^{19}$ Furthermore, the two different lines in the Yellow Sea - South Korea's "Northern Limit Line" and North Korea's "Inter-Korean Military Demarcation Line" have created a large area of disputed waters, as shown in Map 1.

\section{Map 1: South Korea's NLL and North Korea's MDL on the Northern Yellow Sea}

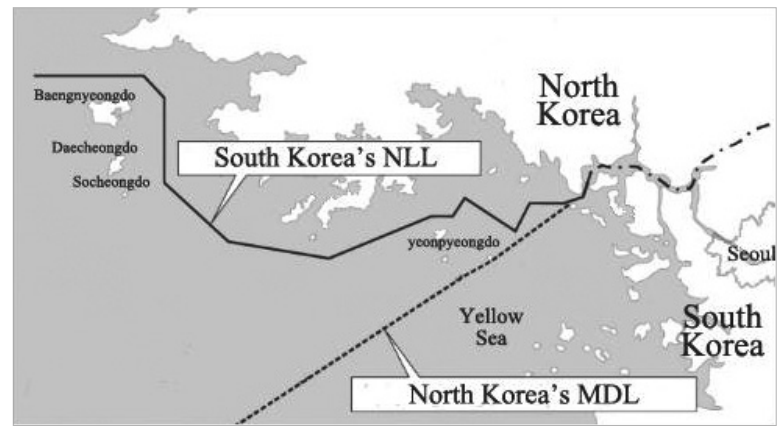

Source: Northern Limit Line (modified by the author), available at http://118.129.184.33/pub/ $\mathrm{docu} / \mathrm{kr} / \mathrm{AM} / 06 /$ AM062001B01/IMAGE/AM06-2001-B01-0210-01.jpg (last visited on Oct. 28, 2012).

In the meantime, the Sino-North Korea fisheries issue has been increasingly concerned. 20 Such a complicated situation will not only easily trigger various disputes and conflicts, which could escalate the conflicts in the Yellow Sea and disrupt the

19 Delimitation of the EEZs between States with opposite or adjacent coasts shall be affected by agreement on the basis of international law in order to achieve an equitable solution. Before an equitable agreement is reached, however, "the States concerned, in a spirit of understanding and co-operation, shall make every effort to enter into provisional arrangements of a practical nature and, during this transitional period, not to jeopardize or hamper the reaching of the final agreement. Such arrangements shall be without prejudice to the final delimitation.” See UNCLOS art. 74(3). According to this provision, many States have signed bilateral fisheries agreement. The Sino-South Korea Fishery Agreement, as a provisional fisheries arrangement on the basis of the good-neighbor principle, was signed, before the delimitation of the EEZ and Continental Shelf between China and South Korea in order to maintain the fishing order in the Yellow Sea.

20 In August 1959, Yellow Sea Fisheries Agreement between the Government of the People's Republic of China and the Government of the Democratic People's Republic of Korea was signed in Beijing. It came into effect in July 1960 for the period of five years valid and then extended for another five years after expiration. In 1972, China and North Korea signed a mutual cooperation agreement on fisheries. After its expiration in 1977, the fisheries cooperation between the two countries has been generally based on their good relationship as well as economic and trade agreements signed by the two governments. It should be noted that on May 8, 2012, North Korea captured three Chinese fishing boats and 29 fishermen in the Yellow Sea. See Fishery Disputes and Maritime Demarcation between China and DPRK (available only in Chinese), May 19, 2012, available at http://international.caixun.com/content/ 20120519/CX020017.html (last visited on Oct. 28, 2012). 
delicate relationships among the neighboring countries, 21 but also prevent China from reaching a finalized maritime demarcation agreement with either North or South Korea. As a consequence, they are inevitably unable to reach a clear-cut resolution of the fisheries dispute.

Today, those fisheries agreements (China-South Korea/China-Japan/Japan-South Korea) are provisional bilateral treaties which have not taken third-party's rights and duties into consideration. These agreements thus create some disputable and overlapping fishing zones. Therefore, it is urgent to hold three-party talks and negotiations among China, Japan, and South Korea.22

\section{B. The Diminishment of Fishery Resources}

Diminishing fishery resources is a very serious issue especially for China for two reasons. First, according to the Sino-South Korea Fishery Agreement, the designations of 'Provisional Waters,' "Waters in Transitional Arrangements" and "Current Fishing Pattern Zones" have reduced Chinese traditional fishing grounds. ${ }^{23}$ Since the 'Provisional Waters' were included in the respective EEZs in 2005, Chinese fishing grounds have been further compressed. Map 2 illustrates these areas in greater detail. Second, the coastal water pollution, caused by industrial development and urbanization, is not only deteriorating the maritime environment, but also affecting the biological resources and reducing marine species. As a result, the fish resources nearby the Chinese coastline are gradually becoming exhausted.24 Because the current boundaries of China's fishing industry can not satisfy the increasing demand of its people, Chinese fishermen have a strong incentive to go fishing further, sometimes crossing the border either intentionally or unintentionally, in order to make a living. This exacerbates the fisheries dispute between China and South Korea.

21 J. Van Dyke, The Republic of Korea's Maritime Boundaries, 18 InT'L J. Marine \& CoAstal L. 509 (2003); M. Valencia \& J. Garmendia, The North/South Korea Boundary Dispute in the Yellow Sea, 27 MARINE PoL'y 143 (2003).

22 Linghua Li, Primary Discussion on Fisheries Agreements between China, Japan and Korea and Establishment of Marine Borderline, 5 Mod. Fisheries INFo. 16 (2006).

23 According to experts, the Sino-South Korean Fishery Agreement forced more than 20,000 Chinese fishing boats out of their traditional fishing grounds in Korean waters near Tsushima Island, Heuksando Island, and Jeju Island. The agreement allows less than 5,500 Chinese boats fishing within the Transitional Waters, among which only 2,796 boats (reduced to 2000 boats in 2005) are permitted to enter South Korean EEZ. This means that most of the Chinese fishing boats are pushed out of traditional fishing grounds to off-shore fishing grounds, competing for the scarce fishery resources. See Bolong Xu, A Response to Sino-South Korean Fishery Agreement, 2 OcEan Dev. \& Mgmt. 49 (2002).

24 Guifang Xue, International Fisheries LaW and Policy and China’s Practice 170 (2008). 
Map 2: Fisheries Zones in the Yellow Sea

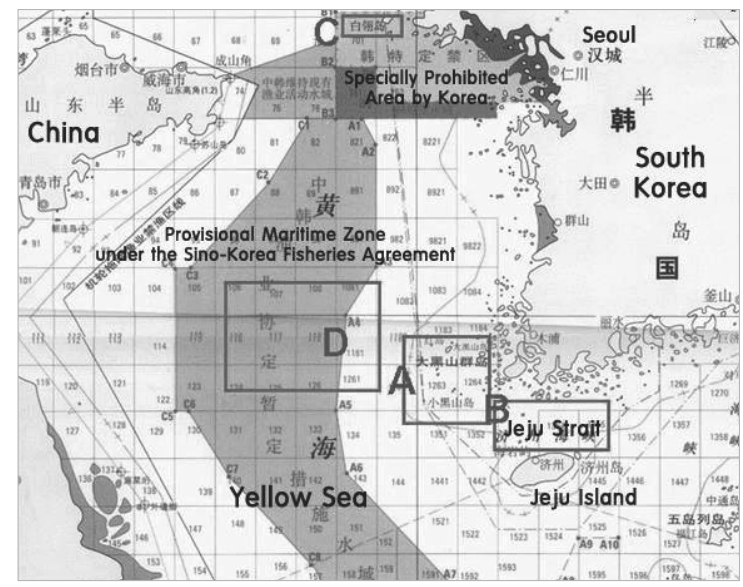

Source: A Schematic Diagram for the Sino-South Korea Fishery Agreement Waters, available at http://www.hudong.com/wiki/\%E3\%80\%8A\%E4\%B8\%AD\%E9\%9F\%A9\%E6\%B8\%94\%E4\%B8\%9A\% $\mathrm{E} 5 \% 8 \mathrm{D} \% 8 \mathrm{~F} \% \mathrm{E} 5 \% \mathrm{AE} \% 9 \mathrm{~A} \% \mathrm{E} 3 \% 80 \% 8 \mathrm{~B}$ (last visited on Oct. 28, 2012).

\section{Difficulties in Relocating Chinese Fishermen}

The Sino-South Korea Fishery Agreement and the Sino-Japanese Fisheries Agreement have painful impact on more than 30,000 fishing boats, 300,000 fishermen, and 1,000,000 households in China. 25 China is also undergoing difficult process of relocating fishermen, who would not give up their means of livelihood handed down from generation to generation, nor have the ability to meet the dramatic challenge within a short period of time. 26 A scholar points out:

South Korea has done a better job than China in the transformation of its fisheries industry, where advanced cultivating fisheries have made fishermen less dependent on fishing operations. However, the much bigger population of Chinese fishermen makes the industrial transformation more difficult than that in South Korea; meanwhile Chinese fishermen's livelihood and education make it impractical for them to make a living by cultivating fisheries which they have never tried before. ${ }^{27}$

27 Lei, supra note 5 , at 35 . 


\section{Technical Violations Caused by Less-educated Fishermen}

For centuries, Chinese fishermen have been fishing in their traditional fishing grounds with their old-fashioned ways. It will thus take time for them to become familiar with and adapt to the rules of the Fishery Agreement and the domestic laws of foreign countries. Many fishermen cannot accept that they are forced out of their traditional fishing grounds mainly due to the change of the legal status of the waters. It is no wonder they are unwilling to abide by the bilateral fisheries agreements. As a consequence, since the effective date of the Sino-South Korea Fishery Agreement, there have been increasing fishing operations that are inconsistent with relevant laws and regulations. According to a statistics from the China Fishery Law Enforcement and Command Center, two-thirds of the 700 fishing boats detained by South Korea from 2008 to 2011 did carry a valid fishing license issued by South Korea, but were detained because their operations were not consistent with the Korean regulations. 28 These small Chinese fishing boats without precise locating devices often enter into the restricted fishing waters by mistake and then get arrested because of illegal fishing. Additionally, some fishermen, driven by economic interests, are not afraid of fines or even being arrested. 29

\section{E. KCG's Rigidity, Indiscrimination, and Illegality in Law Enforcement}

When the fishing season starts in mid-September, Chinese fishermen go for fishing on the sea. However, the KCG designates the 45 days from September 16 to October 30 of each year as the "special punishment period" against illegal fishing by Chinese boats. 30 To combat the increasing difficulty in managing Chinese fishing boats, the KCG has adopted a series of measures to strengthen enforcement since October 2008, allowing its officers to carry firearms, increasing the amount of fines, and taking other enhanced measures. ${ }^{31}$ Currently, the fine for a fishing boat without a fishing license is more than 500,000 RMB and the KCG scrutinizes Chinese fishing boats more frequently and technically. 32

In addition to the increasing fines, the KCG's enforcement is getting more rigid and indiscriminating, sometimes even violating the law. For example, Chinese fishermen

\footnotetext{
28 Keeping a wrong fishing log is one of the most frequent reasons. See Xiong \& Che, supra note 7, at 53; Lei, supra note 5 , at 35 .

29 Xue, supra note 24 , at 209.

30 Xiong \& Che, supra note 7 , at 53.

31 Lei, supra note 5 , at 35 .

32 Xiong \& Che, supra note 7, at 53.
} 
must pay a bond and a 1.5\% - 2\% extra charge to South Korea before the settlement of dispute. 33 On top of that, Chinese fishermen have been allegedly cheated for many times in the process of paying through Korean interpreters or Korean businessmen because they do not understand Korean language.34 After the "Lu Wen Yu incident," the KCG showed a tendency for escalating of physical conflict as shown in "Zhe Tai Yu Yun incident" in 2012.35 Chinese fishermen's violent resistance could be understandable due to these factors. No exit could be found from this vicious circle to the peaceful settlement of the Sino-South Korea fisheries disputes.

\section{Tentative Suggestions for Peaceful Fisheries in the Yellow Sea}

Fishery seems less important than global economic and security issues. However, to the countries around the Yellow Sea, fishery plays an indispensible role in balancing the political relationship. Sometimes fisheries disputes divert the friendly relationship between these States into a hostile one. Therefore, peaceful settlement of the Sino-South Korean fisheries dispute will be significant for the future relationship between the two countries.

The Sino-South Korea Fishery Agreement has established a Joint Fishery Committee ("JFC"), whose representatives are appointed by each government. The JFC may initiate marine resource protection and management, fishing quotas, types of species to be caught, and other conditions for fishing. However, the agreement indicates the following: (1) the recommendations shall be made on the basis of consensus of all representatives from both countries ${ }^{36}$; and (2) both countries should respect the recommendations and "take necessary measures." 37 Nonetheless, it is unclear that to what extent the recommendations are binding on both governments. 38

Another problem is that the Sino-South Korea Fishery Agreement includes no dispute settlement clause. On August 25, 2006, China made an announcement that: "The Government of the People's Republic of China does not accept any of the procedure provided for in Section 2 of Part XV of the Convention with respect to all the categories

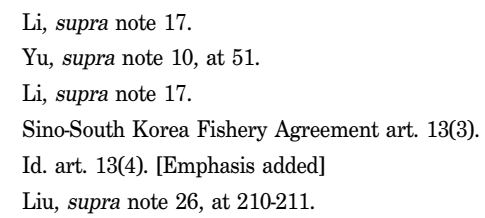


of disputes referred to in paragraph 1 (a) (b) and (c) of Article 298 of the United Nations Convention on the Law of the Sea ("UNCLOS")," 39 while making no specific reservation to the compulsory procedures referred to in Article 287 of the UNCLOS.40 South Korea also released a similar declaration in the same year. 41 As shown by the announcement, China clearly and consistently maintains that disputes should be solved through friendly consultation and direct negotiation between countries directly concerned; countries concerned may also recourse to other dispute settlement means if they so agree. 42 In order to settle the fisheries dispute between China and South Korea, the following measures should be taken:

\section{A. Bilateral Cooperation Should Be Further Promoted}

The Sino-South Korea Fishery Agreement is the second bilateral fisheries treaty that China has concluded with its neighboring countries. 43 That Agreement aims to "ensure the conservation and rational utilization of marine resources of common interest, maintain fishing order, and strengthen their fishery cooperation." 44 The agreement has been highly appraised as "a good start for a new global ocean regime ... [which is] beneficial for China and South Korea (1) to maintain the fishing order, (2) to protect marine resources in the Yellow Sea, and (3) to promote their fisheries cooperation." 45

Article 12 of the Agreement stipulates that: "Both parties should take measures to strengthen cooperation in the scientific research on the conservation and rational exploitation of marine resources." 46 They should thus make efforts to explore new fields and ways of fishery cooperation so as to promote their cooperation to a new level and height. 47 Specifically, China and South Korea should strengthen their cooperation in the following aspects:

First, both parties should enhance their cooperation in conserving and managing fishery resources, as well as promoting a sustainable marine fishery development. China and South Korea may jointly proclaim a summer fishing moratorium or a fishing

See "Article 298 of the UNCLOS," the official website of the P.R.C. Ministry of Foreign Affairs (available only in Chinese), available at http://www.fmprc.gov.cn/chn/gxh/zlb/tyfg/t270754.htm (last visited on June 7, 2012).

40 Junfeng Gu, An Analysis on the Legal Effect of Exception Declaration Delivered by PRC According to Article 298 of UNCLOS, 2 CHINA OCEANS L. REv. 39 (2007).

41 Hui Wu, The Mechanism for Resolving International Dispute of the Law of Sea and its Impact on Diaoyu Islands Dispute, 4 J. U. INT'L REL. 22 (2007).

42 Degong Chen, Recent International LaW of the Sea 541 (2009).

43 In 1997, China signed the fisheries agreement with Japan.

44 Sino-South Korea Fishery Agreement pmbl.

45 Baoying Zhu, The Sino-South Korea Fishery Agreement Comes into Effect, ChINA FisheRIES Y.B. 150 (2002).

46 Sino-South Korea Fishery Agreement art. 12.

47 J. Charney, Central East Asian Maritime Boundaries and the Law of the Sea, 89 AM. J. INT'L L. 747 (1995). 
ban in the 'Provisional Waters'; exchange fishery information and fishery laws and regulations; take joint measures in the conservation and management of straddling fish stocks and highly migratory fish stocks in their respective 'Provisional Waters' and the EEZs, including jointly declaring the total allowable catch and the joint allocation of fishing quotas to fishermen. They may set up a conservation and management fund for fishery resources in the Yellow Sea. At the same time, both countries could take measures to enhance fishery resources, such as building artificial fish reefs and releasing hatchery reared juvenile marine fish to the sea on a regular basis. These measures are aimed at increasing the amount of economically valuable aquatic creatures in the Yellow Sea. Furthermore, the parties can exchange and communicate information on scientific research, statistics about the total catch and fishing effort, and other conservation information regarding commonly concerned fish stocks. 48

Second, China and South Korea should promote cooperation in fish processing in order to expand the market and improve the efficiency of the fishery industry. South Korea's advanced fish processing technology ensures itself a large share in the market of processed aquatic products. Conversely, the fish processing industry in China, though still improving, still lags far behind similar industries in developed countries. Although seventy-five percent of aquatic products are sold after processing in the developed countries, in China, only less than thirty percent of acquatic products are processed. In addition, the poor processing technology leads to lower additional value and competitiveness of Chinese products. 49 It would be thus beneficial for both China and South Korea to communicate and cooperate with each other in the fish processing industry, because China can take this opportunity to introduce highly advanced technology and equipment from South Korea. It will benefit China's fish processing industry, fish trade, and exportation. Meanwhile, South Korean enterprises can improve their productivity in the global market by investing in China and making use of its cheaper labor resources. 50

Third, China and South Korea should make cooperation in the deep-sea fishing industry. Both countries should encourage their deep-sea fishing enterprises to cooperate in terms of capital, technology, market, and other aspects of the enterprise. Both countries should encourage their enterprises to build up joint venture fleets and explore deep-sea fishing grounds. China should provide better labor services for South Korea to meet the labor demand of its domestic enterprises as well as encourage its

\footnotetext{
48 Xiaoyan Du \& Guojiang Ni, Consideration on Fishery Cooperation between China and South Korea, 6 CHINESE FISHERIES ECON. 44 (2007).

49 Id. at 45.

50 Xin Guan, South Korea's Export-Oriented Fisheries, 5 ChINA Fisheries 24-25 (2007).
} 
fishermen to work for Korean deep-sea fishing enterprises. 51

Fourth, China and South Korea should cooperate with each other in the area of scientific and technological research and development. Since both countries have rich human and material resources in the area of scientific research for the purpose of fisheries science, they could coordinate their efforts in conducting scientific research, exploiting marine resources, breeding new species for aquaculture, and improving breeding technologies. China and South Korea are currently carrying out a joint research on serious marine fish diseases and deteriorating marine ecosystem. This joint research will propel their fishery industries forward. Scholars from both the countries should communicate with each other and work out a practical scheme for the sustainable development of fisheries. They can also initiate academic exchanges through a variety of channels, such as mutual visits by scholars, trainings in advanced fishery technology, forums, and joint scientific research programs, so that both China and South Korea can improve their capabilities to generate technological innovation.52

In summary, the fisheries dispute is just one of the many issues lying between China and South Korea. The key to settling this issue is to strengthen strategic mutual trust and cooperation. 53 Cross-border cooperation is the best way to protect marine resources and realize the ultimate goal of sustainability. China and South Korea should not stop their cooperation in the fisheries industry in spite of the current fisheries dispute. Then, the unsettled maritime delimitation will not impede noteworthy goals such as conserving the fish stocks. 54

\section{B. China Should Improve its Supporting Measures Applicable to the Fishery Industry}

First, China should take active measures to develop its deep-sea fishing industry. At present, the most practical way is to relocate the fishermen, fishing in the waters under the fisheries agreements with South Korea and Japan, into the deep-sea fishing zones. It will effectively reduce the population of unemployed fishermen. Given its high threshold of investment, the deep-sea fishing industry cannot develop without governmental supports such as discount loans and subsidy funds. Moreover, China should promote advanced fishing technology. 55

\footnotetext{
Yingliang Xie, Korea Deep Sea Fisheries, 5 Modern Fisheries INFo. 10-12 (2005).

Yingliang Xie \& Yinmei Xu, Fishery Management System in Korea, 9 ModERn FisHeRIES INFo. 9-10 (2005).

Lei, supra note 5 , at 35 .

Xue, supra note 24 , at 179.

Xiong \& Che, supra note 7 , at 53.
} 
Second, China should focus more on maritime culture, fish processing, marine tourism, and leisure fishery instead of the traditional fishing industry. This restructuring would stabilize offshore fisheries and encourage fishermen to develop maritime culture industry. The fish processing industry must be given priority to the restructuring process so as to raise the value added of fishery products. The government should encourage and support fishermen to start new, competitive fishery businesses with more investment and preferential policies. 56

Third, China should encourage fishermen to upgrade equipment on fishing boats, and strengthen its monitoring of these boats. The critically antequated equipment on Chinese fishing boats often leads them to Korean EEZ waters by mistake, thus increasing the risk of fisheries disputes. Special efforts should be made to update equipment and monitor fishing boats. E.g., each boat is required to equip with GPS navigator. Simultaneously, a special agency should be established to monitor all boats and send signals to warn and stop them once they are crossing into alleged Korean waters. Finally, China should be proactive in establishing a Fishermen Basic Life Security System 57 to relieve their living pressure, thus removing the incentive to illegally fish.

\section{China and South Korea Should Build a Workable Joint Law Enforcement Mechanism}

In recent, China and South Korea have been working together towards peaceful settlement of fisheries disputes. However, no workable enforcement mechanism has been established yet, mainly because the KCG, in charge of law enforcement at sea, is not coordinating with the Office of Fisheries Policy of the Ministry for Food, Agriculture, Forestry and Fisheries which is the South Korean representative in the Sino-South Korean fisheries negotiations. Because of this organizational inconsistency, China cannot communicate with the KCG directly and efficiently.

China and South Korea should work together to build a joint enforcement team, with all officers proficient in both Chinese and Korean languages and knowledgeable of the relevant laws of both the countries. Joint law enforcement would not only avoid disputes due to language and cultural differences, but also prevent illegal enforcement activities based on mutual supervision. The specific arrangement for the Sino-South Korean joint enforcement team at sea could be made by the Joint Fishery Committee.

56 Miao Wang \& Qin Liu, Studies on Transitional Issues in Marine Fishery in China, 1 ChINESE FisherIEs Econ. 76-77 (2009).

57 Zhanjie Ju \& Lanfen Liu, Problems and Countermeasures of Dual-transform of Fishermen in the Coastal Region, 3 Chinese Fisheries Econ. 22 (2010). 
Furthermore, China should carry out comprehensive research on the communication mechanisms that have taken place in the cases of Chinese fishermen's detention in South Korea. Ideally, fisheries management departments, from central and local governments, should set up a special agency and employ people who are familiar with the Korean language, Korean law, and management of these cases. They would study relevant Korean laws and regulations, and advocate Chinese fishermen before the South Korean courts. Alternatively, fisheries departments could engage a qualified and prestigious law firm to act on the behalf of Chinese fishermen, as well.

\section{Conclusion}

In summary, Sino-South Korea fisheries disputes have became more violent in recent years. These conflicts are closely inter-related with legal, economic, and political factors. Among them, especially, the political reasons should not be ignored to understand all aspects of East Asian fisheries regime. The Sino-South Korea Fishery Agreement of 2000 can be regarded as a political arrangement against the backdrop of the post-1992 surging economic and trade relationship. The fisheries agreement has been signed in order to define fishery rights and obligations as well as abide by the methods of dispute resolution. However, it has often turned into one of the triggers for disputes since the signing of the Agreement in 2000. It is mainly because the golden fishing waters in the Yellow Sea - traditional fishing grounds for Chinese fishermen - have been put under South Korean jurisdiction. 58 As the coastal fishery resources are diminishing, the SinoSouth Korean Fisheries Agreement has further compressed the living space for Chinese fishermen, who eventually choose to "take their chances" in Korean waters. The increasing number and severity of fisheries disputes not only reflects the living dilemma of Chinese fishermen, but more importantly calls for an urgent settlement of the maritime delimitation between China and South Korea. 
